\title{
The Effect of Probiotic Giving on Body Size Broiler Chicken Aged 2-4 Weeks
}

\author{
Rusli Badaruddin', La Ode Nafiu², Muhammad Amrullah Pagala ${ }^{3}$, La Ode Muh \\ Munadi $^{4}$ \\ 1,2,3,4 Faculty of Animal Science, Universitas Halu Oleo, Indonesia \\ rbadaruddin79@yahoo.com
}

\begin{abstract}
The study aimed to determine the effect of giving different probiotics to the growth rate of several body parts of broiler chickens such as chest circumference, femur length, tibia length, and body length at 2-4 weeks of age with 100 MB 202 platinum strain using BP 11 commercial feed, probiotic supplements. Liquid organics, Lacto probiotics, and local probiotics (tape yeast). The research method used a completely randomized design (CRD) then the data obtained were analyzed employing variance (ANOVA) and if there was a significant effect, it was continued with the Duncan Multiple Range Test (DMRT). The results of the analysis showed that the administration of tape yeast in broiler drinking water showed a significant effect $(p<0.05)$ on the increase in chest circumference, femur length, and body length which was greater than liquid organic probiotics and lacto.
\end{abstract}

Keywords: probiotics; growth; broiler chicken

\section{Introduction}

Broiler chickens are types of poultry as a source of animal protein. Meat request broiler chickens increase because of the price affordable and cheap meat. Broiler chickens have a high growth rate and depending on the feed component. The feed has an important role in the livestock industry and is the biggest cost in the poultry farming industry. Availability of poultry feed must be continuous, and available throughout the year. Feed broilers in general must contain the nutrients needed by livestock because they are the main component of feed. Even though the level of meat consumption Indonesian population broiler enough high, but not accompanied by broiler population and production. The obstacle occurred because the maintenance of broiler feed prices was uncertain.

Success in the broiler business depends on the availability of cheap feed ingredients and able to meet the nutritional requirements of broilers. Methods that can be used to increase the value of feed are through feed additives. Antibiotic residues become dangerous for consumers because antibiotics create resistant microorganisms in the body of humans or livestock such as Salmonella, Escherichia coli, and Clostridium p erfinens. So there need to be bio supplements that are safe for livestock, namely with the use of probiotics in feed. Probiotics are living or growing microbes in the intestine and can provide benefits for the host, either directly or indirectly from its metabolites. Probiotics contain several microbial consortia, including Bacillus sp., Lactobacillus sp., and Saccharomyces cerevisiae use of probiotics star $0.25 \%$ in the ratio can increase weight gain broiler body until the age of 6 weeks and improve fiber course up to $6 \%$.

This study used three types of probiotics, namely liquid organic supplements, Lacto, and local probiotics (tape yeast). The use of probiotics to increase broiler chicken production has been widely carried out but research to see the differences between the three types of probiotics have never been carried out at different ages and this study tried to examine the type of probiotics on the growth rate of several body parts of broiler chickens such as chest circumference, femur length, length tibia, and body length at the age of 2-4 weeks thereby increasing feed digestibility and growth. The effect for each of these probiotics will be seen by observing the growth performance of broiler chickens because body size can be used as an 
economic growth predictor such as body weight, body length, chest circumference, thigh length (femur), and calf-length (tibia). This study aims to determine the effect of giving different probiotics into feed on the growth rate of several body parts (breast circumference, femur length, tibia length, and body length) of broiler chickens aged 2-4 weeks.

\section{Review of Literature}

The use of antibiotics in poultry feed has been widely carried out in increasing its production. However, long-term use of antibiotics can make disease pathogens mutate and become resistant. Patients to determine the profile of antibiotic use and the effectiveness of antibiotics that will be carried out (Ningrurm, 2021). Probiotics are feed supplements derived from live bacteria that can provide benefits to livestock in improving the balance of microflora in the digestive tract so that it is useful in increasing the digestibility of the rumen of livestock or microorganisms that live in a certain medium that is used to balance the digestive tract (Trimudita \& Djaenudin, 2021; Siswantoro et al., 2021; Khothijah et al., 2021; Firdani et al., 2021. The use of probiotics is beneficial because it can increase livestock productivity and can reduce expenditure on feed (Solehudin et al., 2020; Sjofjan et al., 2020), for example in chickens, resulting in improved feed conversion (Megawati et al., 2020; Mas'ad et al., 2020).

Probiotics are an alternative in replacing the role of antibiotics, because they can increase livestock production, digestibility, and can reduce intestinal disease (Azizah et al., 2020; Aurora et al., 2020). Sulistiyanto et al., (2019) Giving probiotics to broilers can improve growth, conversion rates and increase the availability of vitamins and other food substances (Andriani et al., 2020; Wahyuni et al., 2019). Probiotics are feed additives in the form of live beneficial microbes, improving the balance of microorganisms in the digestive tract. The digestive tract contains hundreds of billions of species of bacteria and these bacteria compete with each other for food in the intestines. The type and number of bacteria vary and are always changing over time (Azizah et al., 2018; Afifah et al., 2021). The larger the body size frame, it is expected that there will be more attached muscles to produce larger pieces of the carcass (Ulfa et al., 2019; Nahak, 2019; Nagara et al., 2019; Kurnia, 2019).

\section{Research Methods}

\subsection{Research Location and Time}

The research was carried out from January to February 2021 at the Poultry Livestock Unit Laboratory, Faculty of Animal Science, Halu Oleo University, Kendari, and Southeast Sulawesi.

\subsection{Research Material}

The tools to be used in the study were 20 rectangular cages with a size of $80 \mathrm{~cm}$ x 80 $\mathrm{cm}$ for each unit. The tools used in this research are feeders, drinking containers, digital scales, rice husks, as well as stationery, and a 60-watt incandescent lamp as a source of heat and lighting. The material to be used is broiler strain MB 202 Platinum PT. Japfa Comfeed Indonesia Tbk as many as 100 heads, BP 11 commercial feed, liquid organic supplement probiotics, Lacto probiotics, and local probiotics (tape yeast). 


\subsection{Research Procedure}

The cages were first cleaned by sweeping, brushing, and washing with clean water, then sterilized using a disinfectant by spraying to prevent contamination of pathogenic microorganisms. After the cage was cleaned using a disinfectatnt, the cage was dried seven days and each experimental cage was randomly assigned to consist of 5 broilers. Stages of rearing broiler strain MB 202 Platinum PT. Japfa Comfeed Indonesia Tbk was reared from DOC until the age of 5 weeks, but first, the DOC was given a stress vita to cope with stress. Before treatment drinking water was given, broiler chickens underwent an adaptation period to feed for 7 days. Treatment drinking water was given after the chickens were 8 days old until they were 5 weeks old. Feeding during brooding was carried out ad libitium using BP 11 feed, where drinking water and feed were always cleaned before adding. The feed used in this study was a commercial type BP11, which was produced by PT. Charoen Phokpan Indonesia Tbk with the composition of the feed ingredients used are presented in Table 1.

Table 1. Nutritional composition of feed BP11

\begin{tabular}{lcc}
\hline \multicolumn{1}{c}{ Nutrient level } & Range & Level (\%) \\
\hline Water content & Maximum & 13 \\
Crude protein & Range & $21 \%-23$ \\
Fat & Minimum & 5 \\
Coarse fiber & Maximum & 5 \\
Ash & Maximum & 7 \\
Kalcium & Minimum & 0,9 \\
Phosphor & Minimum & 0,6 \\
\hline
\end{tabular}

Information: Charoen Pokphan (2014)

The treatment was given to drinking water, while the treatment given was liquid organic supplement probiotics, Lacto probiotics, and tape yeast probiotics. Provision of liquid organic probiotic supplements is given, namely $5 \mathrm{ml}$ for one liter of water into drinking water. Giving Lacto probiotics is one bottle cap (10cc) into one liter of water. Next, probiotic yeast tape (1 grain=2.8 gram) for one liter of water. The drinking water treatment was given twice a day, in the morning and evening. The amount of drinking water is $500 \mathrm{ml}$ for one cage plot which consists of five chickens.

\subsection{Research Design}

The design used in this study was a completely randomized design (CRD) which consisted of 4 treatments and each treatment consisted of 4 replications, each replication consisted of 5 chickens. The treatment applied is as follows:

$\mathrm{P} 0=$ No probiotic treatment

P1 = Liquid organic supplement probiotics

P2 = Lacto probiotics

P3 = Tape yeast probiotics

Each of the 4 treatments was repeated 4 times so that there were 16 experimental units. Each experimental unit consisted of 5 chickens so that the total number of chickens used in this study was 80 . The mathematical model used is:

$$
Y_{i j}=\mu+\alpha_{i}+\varepsilon_{i j}
$$




\section{Description:}

$\mathrm{Y}_{\mathrm{ij}} \quad$ : Observed variable value

$\mu \quad$ : General mean

$\alpha_{i} \quad:$ Effect of treatment on-i

$\varepsilon_{\mathrm{ij}} \quad:$ Experimental error from treatment to-i and repeat to- $\mathrm{j}$

\subsection{Data Analysis}

The data to be obtained were analyzed statistically using SPSS software. The data were analyzed by analysis of variance (ANOVA) and if there was a significant effect $(\mathrm{P}<0.05)$ from the treatment, it would be continued with the Duncan Multiple Range Test (DMRT).

\section{Discussion}

\subsection{Chest Size}

The results of observations of the increase and size of the breast circumference of broiler chickens aged 2-4 weeks that were given different probiotics in drinking water are presented in Table 2.

Table 2. Increase in Breast Circumference $(\mathrm{cm})$ Broiler Chickens Given Different Probiotics

\begin{tabular}{|c|c|c|c|}
\hline \multirow{2}{*}{ Treatment } & \multicolumn{2}{|c|}{ Age (Weeks) } & \multirow{2}{*}{$\begin{array}{c}\text { Chest } \\
\text { Circumference }\end{array}$} \\
\hline & II & IV & \\
\hline $\mathrm{P} 0$ & $18.78 \pm 1.16$ & $24.92 \pm 1.17$ & $6.13 \pm 0.32^{b}$ \\
\hline P1 & $17.34 \pm 2.41$ & $24.55 \pm 1.77$ & $7.21 \pm 1.24^{\mathrm{ab}}$ \\
\hline $\mathrm{P} 2$ & $18.89 \pm 0.80$ & $25.04 \pm 0.62$ & $6.15 \pm 0.70^{\mathrm{b}}$ \\
\hline P3 & $17.99 \pm 1.60$ & $25.35 \pm 1.08$ & $7.36 \pm 0.11^{\mathrm{a}}$ \\
\hline
\end{tabular}

${ }^{\mathrm{ab}}$ Different Superscripts in the Same Row Showed Significantly Different Treatment Effects $(\mathrm{p}<0.5)$

Table 2 shows that the mean breast circumference of broiler chickens after administration of different probiotics into drinking water, for the second week of age ranged from 17.34-18.89 cm with the highest mean in treatment P2 and the lowest in treatment P1. While the age of IV weeks ranged from $24.55-25.35 \mathrm{~cm}$ with the highest average in the P3 treatment and the lowest in the treatment P1.

The results of the analysis of variance showed that the provision of different probiotics in drinking water had a significant effect $(\mathrm{P}<0.05)$ on the increase in breast circumference of broiler chickens. Treatment P3 was significantly higher than treatment P2 and P0, but not significantly different from treatment $\mathrm{P} 1$. It is suspected that the administration of tape yeast can function well in increasing the digestibility and absorption of nutrients in the digestive tract. Wibawa et al., (2015), khamir Saccharomyces sp. on tape yeast can increase ration efficiency, and utilization of nutrients, as well as reduce the amount of $\mathrm{N}$ and $\mathrm{P}$ secreted by feces. Farahdiba et al., (2011), that the administration of tape yeast is effective in improving carcass quality, and can increase the percentage of the breast and back of broiler chickens due to the presence of the microbe Saccharomyces sp. which can stimulate the muscle growth of broiler meat. Citrawati et al., (2015), Saccharomyces sp. yeast has the potential as a probiotic agent, to replace the function of antibiotics as growth stimulants. 
The greater the growth in body weight, the larger the chest, because the muscles that respond the most to food conditions are the chest muscles. Nahak (2019) states that in broilers the muscles that respond the most to food conditions are musculus pectoralis (chest muscles) followed by thigh muscles.

\subsection{Femur Length}

The results of observations of the increase and length of the femur of broiler chickens aged 2-4 weeks given different probiotics in drinking water are presented in Table 3 . Table 3 shows that the mean length of the femurs of broilers after the administration of different probiotics into drinking water, for the second week of age ranged from 5.79-6.29 $\mathrm{cm}$ with the highest mean in treatment P2 and the lowest in treatment P1. While the age of IV weeks ranged from 8.11-8.29 $\mathrm{cm}$, with the highest mean in the P3 treatment and the lowest in the treatment P1.

Table 3. Increase in Femur Length $(\mathrm{cm})$ Broiler Chickens Given Different Probiotics

\begin{tabular}{cccc}
\hline \multirow{2}{*}{ Treatment } & \multicolumn{2}{c}{ Age (Weeks) } & \multirow{2}{*}{$\begin{array}{c}\text { Femur Length } \\
\text { Increase }\end{array}$} \\
\cline { 2 - 3 } & II & IV & $2.02 \pm 0.32$ \\
P0 & $6.23 \pm 0.52$ & $8.25 \pm 0.38$ & $2.32 \pm 0.46$ \\
P1 & $5.79 \pm 0.31$ & $8.11 \pm 0.16$ & $2.02 \pm 0.44$ \\
P2 & $6.29 \pm 0.42$ & $8.30 \pm 0.29$ & $2.34 \pm 0.50$ \\
P3 & $5.96 \pm 0.80$ & $8.29 \pm 0.61$ &
\end{tabular}

Different superscripts on the same line show that the treatment has no significant effect $(\mathrm{p}<0.5)$

The results of the analysis of variance showed that the administration of different probiotics in drinking water had no significant effect $(\mathrm{P}>0.05)$ on the increase in femur length in broiler chickens. However, numerically treatment P3 (tape yeast) had a higher femur length than P0 (without probiotics). This is because the microbes found in tape yeast can function as prebiotics and have a positive impact through decreasing pH. Oktaviana et al., (2015), Tape yeast contains types of microorganisms, namely Lactobacillus, Saccharomyces, Streptococcus, Lactococcus, Acetobacter. The positive effects of probiotics Lactobacillus sp. and Saccharomyces sp produce lactic acid so that the protease enzyme works optimally, increases production improves feed efficiency. Putri et al., (2020) that Lactobacillus sp. can lower the $\mathrm{pH}$ of the digestive tract thereby reducing the population of pathogenic bacteria and loosening the bonds of phytic acid in the feed, as a result, the digestibility of minerals such as calcium and phosphorus will also increase. Things according to the opinion of Santosa et al., (2017) that Lactobacillus sp can increase the digestibility of calcium and phosphorus. Calcium and phosphorus are important elements in the formation of bones, including the femur. Bone growth occurs when the animal is still in its infancy, which includes the process of compaction and the arrangement of the bone matrix, minerals such as calcium and phosphorus are important elements in the formation of the bone matrix.

\subsection{Tibia Length}

The results of observations of the increase in tibia length of broiler chickens aged 2-4 weeks given different probiotics in drinking water are presented in Table 4.

Table 4. Tibia Length Gain $(\mathrm{cm})$ Broiler Chickens Given Different Probiotics 


\begin{tabular}{cccc}
\hline \multirow{2}{*}{ Treatment } & \multicolumn{2}{c}{ Age (weeks) } & Tibia Length \\
\cline { 2 - 3 } & II & IV & Increase \\
\hline P0 & $6.92 \pm 0.55$ & $7.98 \pm 0.99$ & $2.07 \pm 0.45$ \\
P1 & $6.97 \pm 0.20$ & $7.98 \pm 0.97$ & $2.01 \pm 0.24$ \\
P2 & $6.75 \pm 0.50$ & $7.73 \pm 1.05$ & $2.26 \pm 0.63$ \\
P3 & $7.20 \pm 0.29$ & $8.16 \pm 1.00$ & $2.12 \pm 0.36$ \\
\hline
\end{tabular}

Different superscripts on the same line showed no significant effect on treatment $(p<0.5)$.

Table 4 shows that the average length of the tibia of broiler chickens after administration of different probiotics into drinking water, for the second week of age ranged from 6.75-7.20 cm, with the highest mean in treatment P3 and the lowest in treatment P2. While the age of IV weeks ranged from $7.73-8.16 \mathrm{~cm}$, with the highest mean in treatment P3 and the lowest in treatment P1.

The results of the analysis of variance showed that the administration of different probiotics in drinking water had no significant effect $(\mathrm{P}>0.05)$ on the increase in tibia length of broiler chickens. However, these results illustrate that the tibia length tends to be higher in the P3 (tape yeast) treatment. This is thought to be caused by the role of microbes in tape yeast to improve digestive tract function and absorption of $\mathrm{Ca}$ and protein. These results are by the research Sari et al., (2015) that the administration of Saccharomyces sp. into laying hens rations increased absorption of calcium (Ca) and protein. Ziaie et al., (2011) reported that probiotic supplementation can improve the digestibility and availability of nutrients such as calcium $(\mathrm{Ca})$ and phosphorus $(\mathrm{P})$. Most of the calcium absorbed by the body will be stored in the bones and used as a component of the bone matrix (Aurora et al., 2020), including the growth of the tibia bone in chickens.

\subsection{Body Length}

The results of observations of the increase and body length of broiler chickens aged 2-4 weeks who were given different probiotics in drinking water are presented in Table 5.

Table 5. Increase in Body Length $(\mathrm{cm})$ Broiler Chickens Given Different Probiotics

\begin{tabular}{cccc}
\hline \multirow{2}{*}{ Treatment } & \multicolumn{2}{c}{ Age (weeks) } & $\begin{array}{c}\text { Body Length } \\
\text { Gain }\end{array}$ \\
\cline { 2 - 4 } & II & IV & \\
\hline P0 & $13.19 \pm 0.67$ & $16.08 \pm 1.14$ & $2.89 \pm 1.21$ \\
P1 & $12.43 \pm 0.30$ & $15.29 \pm 0.43$ & $2.87 \pm 0.33$ \\
P2 & $12.58 \pm 0.53$ & $15.88 \pm 0.87$ & $3.30 \pm 0.99$ \\
P3 & $12.53 \pm 0.49$ & $16.69 \pm 0.47$ & $4.17 \pm 0.91$
\end{tabular}

Different superscripts on the same line showed no significant effect on treatment $(\mathrm{p}<0.5)$

Table 5 shows that the average body length of broiler chickens after administration of different probiotics into drinking water, for the age of 2 weeks ranged from $12.43-13.19 \mathrm{~cm}$ with the highest mean in treatment P0 and the lowest in treatment P1. While the age of IV 
weeks ranged from 15.29-16.69 $\mathrm{cm}$ with the highest mean in the P3 treatment and the lowest in the treatment P1.

The results of the analysis of variance showed that the administration of different probiotics in drinking water had no significant effect $(\mathrm{P}>0.05)$ on the increase in body length of broiler chickens. This shows that the average body length gain of each treatment in this study was not statistically much different, but numerically the P3 treatment showed a higher body length gain than the other treatments. Oktaviana et al., (2015), Tape yeast contains types of microorganisms that can increase the digestibility and absorption of nutrients in feed, namely Lactobacillus and Saccharomyces. Sari et al., (2015) gift Saccharomyces sp. into chicken rations increased absorption of calcium (Ca) and protein, while Lactobacillus sp. can produce lactic acid bacteria (LAB) in the digestive tract, increasing the number will lower the pH value (Utama et al., 2020). The digestive tract will become healthier which then the development of intestinal villi will increase, so that digestibility and absorption of nutrients increases, especially protein and calcium (Aurora et al., 2020). Syafitri et al., (2015) state that the mechanism that occurs is that the protein will bring calcium into the intestinal mucosal cells or what is often referred to as calcium-binding protein (Ca-BP), then transported to the blood and circulated to the body and then into the tissues that need it such as bone and flesh.

\section{Conclusion}

Based on the results of the study, it can be concluded that the administration of tape yeast probiotics in drinking water of broiler chickens had a significant effect $(\mathrm{P}<0.05)$ on the increase in chest circumference, femur length, tibia length, and body length. However, the administration of liquid organic probiotics and Lacto in the drinking water of broiler chickens did not increase the increase in chest circumference, femur length, tibia length, and body length of broiler chickens.

\section{References}

Afifah, H. N., Santoso, H., \& Syauqi, A. 2021. Addition of Monensin Antibiotic Concentration and Its Effect on Broiler Chicken Performance (Gallus Gallus Domestica) Biosaintropis. 6(2), 40-45.

Andriani, A. D., Lokapirnasari, W. P., Karimah, B., Hidanah, S., Al-Arif, M. A., Soeharsono, S., \& Harijani, N. (2020). Effectiveness of Probiotic Lactobacillus casei and Lactobacillus Rhamnosus as a Substitute for Antibiotic Growth Promoter against Total Cholesterol, Low-Density Lipoprotein, and High-Density Lipoprotein Broiler. Jurnal Medik Veteriner. 3(1), 114-122.

Aurora, N. E., Mahfudz, L. D., \& Sarjana, T. A. 2020. Potential of Garlic and Lactobacillus Acidophilus as Synbiotics on Characteristics of Broiler Chicken Bones. Jurnal Sain Peternakan Indonesia. 15(4), 375-382.

Azizah, N. K., Sarmanu, S., Utomo, B., Sabdoningrum, E. K., Lokapirnasari, W. P., \& Supranianondo, K. 2020. Effect of Probiotic Lactic Acid Bacteria in Drinking Water on Broiler Feed Conversion. Journal of Basic Medical Veterinary. 9(2), 86-91. Https://Doi.Org/10.20473/Jbmv.V9i2.28587.

Azizah, N., Suradi, K., \& Gumilar, J. 2018. Effect of Concentration of Lactic Acid Bacteria Lactobacillus Plantarum and Lactobacillus Casei on Microbiological and Chemical Quality of Probiotic Mayonnaise. Jurnal Ilmu Ternak Universitas Padjadjaran. 18(2), 79-85. Https://Doi.Org/10.24198/Jit.V18i2.19771.

Citrawati, G. A. O., I. G. N. G. Bidura \& I. A. P. Utami. 2015. The appearance of broiler chickens aged 1-5 weeks fed rations with yeast culture supplementation Saccharomyces sp. as a source of probiotics. Jurnal Peternakan Tropika. 3(1), 1-12. 
Farahdiba, F., U. Santoso \& Kususiyah. 2011. Pengaruh Aras Protein dan Ragi Tape terhadap Kualitas Karkas dan Deposisi Lemak pada Ayam Broiler. Jurnal Sain Peternakan Indonesia. 6(1): 47-54.

Firdani, A. P., Pamukas, N. A., \& Tang, U. M. 2021. Effect of Probiotic Administration on Growth Rate and Survival of Eel (Monopterus Albus) in Biofloc System. Aquatic Science. 9(2), 99-107.

Hanum, P.S., Darmawan, N.M.E., Hasmono, D. (2021). Practical Analysis Antibiotics Use for Covid 19 Patients. Budapest International Research in Exact Sciences (BirEx) Journal Vol 3 (4): 274-290.

Khothijah, S., Erwan, E., \& Irawati, E. 2021. Performa Ayam Broiler Yang Diberi Ekstrak Daun Jambu Mete (Anacardium Occidentale Linn) Dalam Air Minum. Jurnal Ilmu Nutrisi Dan Teknologi Pakan. 19(1), 19-23.

Kurnia, D. A. 2019. Pertambahan Bobot Badan Harian (PBBH) Pada Ayam Layer Starter Grower Yang Diberi Resveratrol Tepung Biji Anggur. Jurnal Ternak. 10(1), 7-11.

Mas'ad, K., Lokapirnasari, W. P., Arif, M. A. A., Soeharsono, S., Kurnijasanti, R., \& Harijani, N. 2020. Potensi Probiotik Terhadap Feed Efficiency Dan Egg Mass Pada Ayam Petelur. Jurnal Medik Veteriner. 3(2), 203-207.

Megawati, N. I., Dhamayanti, Y., Purnama, M. T. E., Soeharsono, S., Yudhana, A., \& Yunita, M. N. 2020. Pola Pertumbuhan Ayam Broiler Strain Lohmann Berdasarkan Osteometri Tulang Sayap. Jurnal Medik Veteriner. 3(2), 216-223.

Nagara, R. L. K., Kismiati, S., Setyaningrum, S., \& Mahfudz, L. D. 2019. Massa Protein Dan Kalsium Daging Ayam Broiler Akibat Penambahan Sinbiotik Dalam Ransum. Indonesian Journal of Animal Science. 21(3), 198-204.

Nahak, A. T. 2019. Effect of Addition of Probio in Feed to Live Weight, Carcass Weight, Breast Weight, Weight of Upper and Lower Thighs of Broiler Chickens. JAS. 4(2), 1820. Https://Doi.Org/10.32938/Ja.V4i2.563

Oktaviana, A. Y., D. Suherman \& E. Sulistyowati. 2015. Pengaruh ragi tape terhadap pH, bakteri asam laktat dan laktosa yogurt, Jurnal Sain Peternakan Indonesia. 10(1), 22-31.

Putri, R. A. G. A. S., E. Suprijatna dan D. Sunarti. 2020. The Effect of Additives in the Ration in the Form of Combination of Cassava Peel with Lactobacillus Sp. on the Exterior Quality of Quail Eggs Laying Period. Jurnal Sain Peternakan Indonesia. 15(2), 148-154.

Santosa, B., E. Fitasari \& G. Suliana. 2017. Produksi pakan fungsional mengandung tiga senyawa bioaktif dari ampas tahu dengan menggunakan Mikroba Effective Microorganism-4 dan Lactobacillus plantarum. Buana sains. 17(1), 25-32.

Sari, J. M., T. Kurtini \& M. Hartono. 2015. Pengaruh pemberian probiotik dari mikroba lokal terhadap tebal kerabang, penurunan berat, dan nilai haugh unit telur yang disimpan sepuluh hari. Jurnal Ilmiah Peternakan Terpadu. 3(3), 157-162

Siswantoro, D., Prasetyo, A. F., \& Kusuma, S. B. 2021. Efektivitas Fitobiotik Bawang Putih Terfermentasi Terhadap Produktivitas Ayam Broiler. Indonesian Journal of Animal Science. 23(1), 74-81.

Sjofjan, O., Adli, D. N., Natsir, M. H., \& Kusumaningtyaswati, A. 2020. Pengaruh Kombinasi Tepung Kunyit (Curcuma Domestica Val.) Dan Probiotik Terhadap Penampilan Usus Ayam Pedaging. Jurnal Nutrisi Ternak Tropis Dan Ilmu Pakan. 2(1), 19-24.

Solehudin, S., Antonius, A., \& Ginting, S. P. 2020. Suplementasi Probiotik dan Senyawa Fitokimia Terhadap Performan, Persentase Komponen Asam Lemak Terbang, Total Bakteri Dan Protozoa Cairan Rumen. Jurnal Agripet. 20(1), 63-69.

Sulistiyanto, B., S. Kismiati dan C. S. Utama. 2019. Tampilan produksi dan efek imunomodulasi ayam broiler yang diberi ransum berbasis wheat pollard terolah. Jurnal Veteriner. 20(3), 352-359 
Syafitri, Y.E., V. D. Yunianto \& N. Suthama. 2015. Pemberian ekstrak daun beluntas (Pluchea indica Less) dan Klorin terhadap Massa Kalsium dan Massa Protein Daging pada Ayam Broiler. Animal Agriculture Journal. 4(1), 155-164.

Trimudita, R. F., \& Djaenudin, D. 2021. Enkapsulasi Probiotik Lactobacillus Sp. Menggunakan Dua Tahap Proses. Jurnal Serambi Engineering. 6(2), 1832-1841.

Ulfa, A., Akbar, M., Ali, M., \& Akbar, J. 2019. Difusi Produk Bioteknologi "Probiotik" Untuk Meningkatkan Produksi Ternak Ruminansia Di Desa Lelede Kecamatan Kediri, Lombok Barat. Jurnal Gema Ngabdi. 1(2), 56-64.

Utama, C. S., S. Sugihartodan \& R. A. Putri. 2020. Kualitas mikrobiologi limbah kubis fermentasi dengan penambahan vitamin dan mineral. Jurnal Ilmiah Peternakan Terpadu. 8(3), 120-125.

Wahyuni, A. E. T. H., Prakasita, V. C., Nahak, T. E. M., Tae, A. V., Chandra, J., Ajiguna, A., Adrenalin, S. L., Imanjati, L. N., \& Fauziah, I. 2019. Peluang Imbuhan Pakan HerbalProbiotik Komersial "Promix ${ }^{\circledR}$ " Sebagai Pengganti Antibiotic Growth Promoter (AGP) Pada Ayam Pedaging Yang Diberi Vaksin ND. Jurnal Sain Veteriner. 37(2), 180-184. Https://Doi.Org/10.22146/Jsv.48614

Wibawa A. A. P., I. W. Wirawan dan I. B. G. Pratama. 2015. Peningkatan nilai nutrisi dedak padi sebagai pakan itik melalui biofermentasi dengan khamir. Majalah Ilmiah Peternakan. 18(1), 11-16.

Ziaie, H., M. Bashtani, M. A. Torshizi, H. Naeeimipour, H. Farhangfar, \& Zeinali, A. 2011. Effect of antibiotic and its alternatives on morphometric characteristics, mineral content and bone strength of tibia in ross broiler chickens. Global Veterinaria. 7(4), 315-322. 